Mr Aleksandar Radovanov sudija Okružnog suda u Novom Sadu

\title{
NEKA SPORNA PITANJA U PRIMENI NOVOG ZAKONA O IZVRŠNOM POSTUPKU*
}

Novi Zakon o izvršnom postupku je donet 30 . juna 2000. godine $\mathrm{i}$ stupio na snagu 8. jula 2000. godine (Službeni list SRJ, broj 28/2000), osim nekih odredaba koje stupaju na snagu 1. januara 2001. godine.

Osnovna intencija novog ZIP-a je da se postupak prinudnog izvršenja učini bržim i efikasnijim. Dosadašnji ZIP iz 1978. godine je pružao preteranu zaštitu dužniku, a relativno je malo vodio računa o interesima poverilaca. U tom smislu neka nova rešenja predstavljaju napredak u odnosu na ranije stanje (npr. kod izvršenja prodajom nepokretnosti gde su predviđene novine koje idu u prilog poboljšanju položaja poverioca i bržem i efikasnijem sprovođenju izvršenja).

Međutim, novi ZIP je već na startu otvorio čitav niz spornih pitanja na koje sudska praksa treba da dâ odgovore. Opšti je utisak da uprkos dobroj nameri zakonodavca da ubrza postupak izvršenja, nova rešenja su stavila u nepovoljan položaj dužnika i treća lica u izvršnom postupku u zaštiti njihovih prava i interesa, pa se s pravom može reći da novi ZIP nije pogodio pravu meru stvari odnosa poverilac-dužnik. Bez namere da se detaljno elaboriraju odredbe novog ZIP-a u ovom radu ću ukazati samo na neka rešenja koja po našem mišljenju izazivaju dileme i predstavljaju neadekvatno regulisanje konkretnih pravnih instituta, a što se može odraziti i u radu sudova.

Pre svega, osnovna je zamerka što je ukinuta žalba kao redovan pravni lek u izvršnom postupku. Time je povređeno ustavno pravo na žalbu (član 26. stav 2. Ustava SRJ) i samim tim se postavlja pitanje ustavnosti ovih odredaba ZIP-a koje regulišu materiju pravnih lekova. U vezi sa ovim, a imajući u vidu odredbu člana 262. novog ZIP-a da će se po-

* Rad primljen: 7. XI 2001. 
stupak izvršenja i obezbeđenja koji je započet do dana stupanja na snagu novog Zakona okončati po odredbama novog ZIP-a, odmah se postavlja kao sporno pitanje: šta raditi sa izjavljenom žalbom u vreme važenja ranijeg ZIP-a? U odgovoru na ovo pitanje moguća su tri rešenja:

1) Odbaciti žalbu kao nedozvoljenu po novom ZIP-u,

2) tretirati žalbu kao prigovor pa vratiti predmet opštinskom sudu da u veću trojice sudija odluči kao po prigovoru ili

3) meritorno odlučiti o žalbi. merke.

Prihvatanjem bilo kog od ovih rešenja mogu se staviti ozbiljne za-

Ako se prihvati prvo rešenje da se žalba odbaci kao nedozvoljena, stoji ozbiljna primedba da su stranke oštećene, jer je žalba izjavljena u vreme kada je bila dozvoljena. Time je uskraćeno pravo stranke na pravni lek što je nedopustivo.

Ako se prihvati drugo rešenje, stoji ozbiljna primedba da je o prigovoru već odlučeno. Istina, odlučio je izvršni sudija kao pojedinac, ali je činjenica da je o prigovoru odlučeno, te se postavlja pitanje kako se može dva puta odlučivati o prigovoru.

Ako se prihvati treće rešenje, stoji ozbiljna primedba da se postupa direktno suprotno novom Zakonu koji ne predviđa žalbu kao pravni lek i koji ne predviđa nadležnost okružnog suda kao dugostepenog suda u izvršnom postupku.

Posebno, mislimo da nije dobro rešenje što je prigovor predviđen kao remonstrativni pravni lek tako da se u okviru istog suda odlučuje i u prvom i u drugom stepenu.

U vezi sa ovim otvara se još jedno novo pitanje: Ko može da čini sastav ovog veća koje odlučuje po prigovoru? Da li može i postupajući izvršni sudija da bude član, ili čak i predsednik ovog veća trojice? Po našem mišljenju, bez obzira na to što izričite zakonske zabrane nema, u sastav ovog veća ne bi mogao da uđe izvršni sudija koji postupa u tom predmetu, jer se to kosi sa osnovnim principima nezavisnog i nepristrasnog sudovanja.

Da zaključimo: daleko bolje rešenje je bilo da je ostala žalba kao redovan pravni lek i da po žalbi odlučuje okružni sud kao drugostepeni sud. Statistički podaci pokazuju da ovakvo zakonodavno rešenje nije znatnije uticalo na brzinu i efikasnost izvršnog postupka, te nije bilo razloga za ovakvu izmenu ZIP-a. Naprotiv, ovakvo rešenje će izazvati probleme naročito kod-sudova sa malim brojem sudija, kojih ima dosta u Republici, jer neće biti u mogućnosti da formiraju kompetentno veće i gubiće puno vremena na rešavanju predmeta po ovim prigovorima na uštrb svojih drugih redovnih poslova i zadataka.

Drugo važno sporno pitanje koje će se u praksi pojaviti jeste pitanje upućivanja na parnicu radi nedopustivosti izvršenja, jer ovo više po novom ZIP-u nije moguće. Naime, novi ZIP ne predviđa ni izlučnu, ni opozicionu, ni opugnacionu tužbu, što može dovesti u praksi do velikih problema, kako u već postojećim predmetima, tako i u novim predmetima. 
Ovde se postavlja pitanje kako postupati u predmetima radi nedopustivosti izvršenja gde je doneta prvostepena odluka i izjavljena žalba? Opet se pojavljuje problem pravnog leka i nadležnosti suda, jer niti postoji žalba kao pravni lek, niti nadležnost okružnog suda kao drugostepenog suda, a takođe novim odredbama ZIP-a nisu ni predviđene tužbe za nedopustivost izvršenja, osim kod prodaje nepokretnosti. Sve ovo ukazuje da prelazna i završna odredba iz člana 262. novog ZIP-a kojim je predviđena retroaktivna primena zakona je stvorila čitav niz problema koje će sudska praksa morati da rešava.

Svakako da ce biti potrebno kroz sudsku praksu preispitati ovakvo zakonodavno rešenje u pogledu položaja i prava trećih lica u izvršnom postupku. Bez obzira na to što je bilo određenih zloupotreba i pokušaja odugovlačenja izvršnog postupka u cilju sprečavanja namirenja poverilaca, smatram da izostanak ovih instituta u novom ZIP-u nema opravdanja i više ugrožava zakonitost postupka izvršenja nego što ga ubrzava.

Takođe i izostanak instituta odlaganja izvršenja na predlog dužnika, kao i mogućnost intervencije javnog tužioca u opravdanim slučajevima, neće značajnije doprineti ubrzanju i efikasnosti izvršnog postupka, a mogu u određenim slučajevima da prouzrokuju ozbiljne posledice prilikom sprovođenja izvršenja. Zbog toga ovo nije trebalo generalno ukinuti, već preciznije regulisati u novom ZIP-u, kako bi se mogućnost zloupotrebe ovih instituta svela na minimum.

Sporno je i pitanje privremenih mera, naime, koji pravni lek se može izjaviti i ko o njemu odlučuje? Ovo pitanje se dodatno komplikuje s obzirom na doneto pravno shvatanje Vrhovnog suda Srbije od 19. 11. 1996. godine koje glasi: „Rešenje o određivanju privremene mere je uvek rešenje o izvršenju koje se sprovodi u granicama određenih tim rešenjem bilo da se određuje po odredbama ZIP-a, ili drugih zakona, i bez obzira na to da li se privremena mera određuje u izvršnom, parničnom ili vanparničnom postupku. Stoga dužnik rešenje o određivanju privremene mere i u parničnom i vanparničnom postupku u smislu člana 244. a u vezi sa članom 48. ZIP-a, može pobijati samo prigovorom u tom postupku. Žalba dužnika, izjavljena protiv rešenja o privremenoj meri ima se smatrati prigovorom, o kome na osnovu člana 49. ZIP-a odlučuje onaj prvostepeni sud koji je privremenu meru odredio".

Ovo shvatanje je suprotno ranijem shvatanju Vrhovnog suda Vojvodine gde se pravila razlika između privremenih mera donetih u parničnom i vanparničnom postupku i privremenih mera donetih u izvršnom postupku. Mislimo da pravni lek kod privremenih mera donetih u parničnom i vanparničnom postupku treba da bude žalba, a kod privremenih mera donetih u izvršnom postupku prigovor. O žalbi treba da odlučuje okružni sud kao drugostepeni sud, a o prigovoru veće trojice sudija opštinskog suda. Posebno kada se rešenje o privremenoj meri donosi zajedno sa odlukom o glavnoj stvari, što je dosta čest slučaj u praksi, javlja se apsurdna situacija da u tom slučaju kada se izjavi pravni lek treba razdvojiti postupak, pa vratiti opštinskom sudu da u veću trojice reši po prigovoru 
protiv donete privremene mere, a zatim predmet ponovo dostaviti okružnom sudu da reši po izjavljenoj žalbi na odluku o glavnoj stvari. Apsurdnost je tim veća što privremena mera ima dejstvo samo do pravnosnažnog okončanja parnice, pa u slučaju odbijanja žalbe i potvrde prvostepene odluke rešenje o privremenoj meri postaje u većini slučajeva bespredmetno.

I na kraju kada je reč o normativno-pravnom regulisanju izvršnog postupka treba ukazati da su od posebnog značaja - regulisanje sprovođenja izvršenja u radnim sporovima, jer u dosadašnjoj sudskoj praksi je tu bilo velikih zloupotreba od strane firmi, koje su na sve moguće načine sprečavale radnika da se vrati na posao. Zatim, postupak izvršenja kod oduzimanja malodobnog deteta od jednog roditelja i davanja drugom roditelju i u privrednim sporovima naročito kod dupliranja funkcije direktora, upravnih odbora i drugih organa preduzeća.

Ono što i „stari” i ,novi” ZIP nisu rešili, a što po našem mišljenju u dobroj meri utiče na brzinu i efikasnost sprovođenja izvršenja to su kadrovska i organizaciono-tehnička pitanja, koja kada bi se dobro rešila, postupak izvršenja bi dovelo do maksimalne ažurnosti i efikasnosti. Ovde najviše mislimo na postupak izvršenja na pokretnim stvarima, koji se u praksi često vrlo neuspešno sprovodi, a mišljenja smo da sa dobrom organizacijom zaplene, transfera i prodaje ovih stvari, u $70 \%$ slučajeva postupak prinudnog izvršenja bi ostvario svoj cilj, a to je efikasno namirenje potraživanja poverilaca. 